\title{
Health vulnerabilities in adolescence: socioeconomic conditions, social networks, drugs and violence
}

\author{
Dener Carlos dos Reis ${ }^{1}$ \\ Thiara Amanda Corrêa de Almeida² \\ Mariane Mendes Miranda ${ }^{2}$ \\ Rodrigo Henrique Alves ${ }^{3}$ \\ Anézia Moreira Faria Madeira ${ }^{1}$
}

\begin{abstract}
Objective: to analyze the health vulnerabilities in adolescence associated with socioeconomic conditions, social networks, drugs and violence from the perspective of students. Method: cross-sectional study with 678 students between 14-15 years old in Contagem, Brazil. A selfadministered questionnaire divided into modules by subject was used. Quantitative, descriptive and stratified analyses were performed by sex. Results: high percentage of adolescents (40.4\%) were beneficiaries of Government financial support called "Bolsa Família" and 14.6\% had a job, $57.1 \%$ and $23.6 \%$ had tried alcohol and tobacco, respectively. We identified $15 \%$ of aggression and $26.7 \%$ of bullying. The majority informed they never/rarely talk to parents about the daily difficulties (64.5\%) and 22\% reported insomnia and/or feelings of loneliness. Conclusion: the results indicated that there is a need to intensify educational activities that seek to develop cognitive, affective and social skills aimed at improving the way adolescents face the vulnerabilities, in these activities, nursing has a fundamental role.
\end{abstract}

Descriptors: Adolescent Health; Primary Health Care; Vulnerability Study.

\footnotetext{
${ }^{1}$ PhD, Adjunct Professor, Escola de Enfermagem da Universidade Federal de Minas Gerais, Belo Horizonte, MG, Brazil.

2 Undergraduate student in Nursing, Escola de Enfermagem , Universidade Federal de Minas Gerais, Belo Horizonte, MG, Brazil.

${ }^{3}$ Doctoral Student, Instituto de Ciências Biológicas, Universidade Federal de Minas Gerais, Belo Horizonte, MG, Brazil.
} 


\section{Introduction}

Adolescence refers to a period of maturation of the individual who is subject to social, cultural and environmental influences, with exposure to different situations of vulnerability to his/her health. The challenge faced by the National Policy of Full Health Care for Adolescents and is to program and develop actions that fully meet the demands related to the different vulnerabilites of adolescents' health in our country ${ }^{(1)}$.

In general, the concept of vulnerability is supported by the argument that the structural dimension of the reality, articulated to the objective and subjective needs of individuals and groups, in addition to producing different levels of exposure to harm to health, may reduce the capacity of subjects to make independent decisions with regard to questions of health and the collectivity in which they live. Thus, one could say that vulnerability of health is strongly articulated by discussions about the rights of the person, social control, autonomy and empowerment(2).

However, this argument is based on the notion that a person who is legally of age, capable of freely deciding about the questions of his/her life, and consequently bear the results of his/her decisions, is autonomous(2). From this perspective, adolescents represent a group in which vulnerability and autonomy are themes that need to be better investigated and debated in society in general. In addition, health professionals consider the vulnerabilities associated with the risk/use of drugs, violence and early sexual practice without protection difficult to approach because they involve cultural, social and religious aspects ${ }^{(3-4)}$.

The scenario is aggravated when health care in adolescence, in this case, within the scope of Primary Health Care $(\mathrm{PHC})$, by means of the Family Health Strategy and the School Health Program (SHP), does not consider the possible experiences and autonomy of adolescents in the face of the contexts of vulnerability prevalent in this age group. Coping with this problem demands an approximation of the health program to the needs and the manner in which these individuals problematize and face the situations of vulnerability in the local and municipal sphere.

In view of the foregoing, the aim of this study was to analyze the vulnerabilities to health in adolescence, associated with socioeconomic conditions, the social networks, drugs and violence from the perspective of adolescent schoolchildren in the Municipality of Contagem, Minas Gerais, Brazil. It is hoped that this study may subsidize the development of health care actions in adolescence $b$ the FHS and SHP, in which nursing plays a fundamental role.

\section{Method}

This was a cross-sectional, exploratory/descriptive study with a quantitative and qualitative approach, conducted in the municipality of Contagem, Minas Gerais. In 2011, when this study was conducted, there were 50 municipal public schools, linked to six educational management nuclei, of which 28 were SHP. In this year the population covered by the FHS corresponded to $48 \%$ of the population, cared for by 88 teams in 21 basic care units.

Of the total number of 5.074 pupils in the 9 th year of primary schooling of the 50 public schools eligible to participate in the study, the sample was composed of 715 adolescents from 15 schools from the 06 municipal educational nuclei. The stages of composing the sample were: draw of the participating schools in each educational management nucleus, considering their representativeness in the total number of schools in the municipality. At each school groups were drawn which totaled the number of pupils foreseen in the sample calculation. To calculate the sample, a level of significance of $5 \%$, prevalence of $50 \%$ and margin of $10 \%$ was considered, due to the variability of the event investigated. All the pupils in each of the groups drawn were invited to participate.

There were 37 losses related to refusal to participate, or non presentation of the Term of Free and Informed Consent (TFIC) duly signed by the father/person responsible, so that the final population was composed of 678 adolescents, with an age-range between 14 and 15 years. The choice to work with this age-range and level of schooling considered the perspective of the imminence of entering middle school, in which the adolescents' exposure to the vulnerabilities of health and dropping-out from school appears to intensify.

Data were collected by means of a structured, selfapplied questionnaire, divided into modules by subject, such as mental health, use of tobacco and alcohol, drug use, physical activity, social network, violence, sexuality and hygiene. As reference, the questionnaire recommended by the World Health Organization was used 
to evaluate the risk factors and behaviors of adolescents between the ages of 13-15 years ${ }^{(5)}$. The instrument was pre-tested in a group of 30 pupils at a school that did not participate in the study in Contagem, MG. For this study, information was considered about socioeconomic conditions (receipt of "Bolsa Família" (family aid grant), work in adolescence and community problems), social networks (dialogue with parents, number of friends, feeling of loneliness and insomnia, time of use of the web, digital games and TV), knowledge/use of drugs (alcohol, tobacco, marijuana, ecstasy, crack, cocaine, others) and reports of violence (school and family community). As regards drugs, they were asked only if that had ever tried them, and only for tobacco was the pupil asked whether he/she continued to make use of it at the time of the interview.

The software program Statistical Package for the Social Sciences $\left(\right.$ SPSS $^{\circledR}$ ) version 18.0 (SPSS Inc., Chicago, USA), was used to perform descriptive analysis and stratification by sex. In this stratified analysis Pearson's Chi-square test, at a level of significance of $p$ $\leq 0.05$, was used to evaluate the difference between the frequencies according to the participant's sex.

All the ethical recommendations with regard to research in human beings, in accordance with Resolution 196/86 of the Ministry of Health. foreseen in the Declaration of Helsinki were complied with. The study was approved by the Research Ethics Committee of the Federal University of Minas Gerais (COEP - UFMG), Protocol number 0091.0.203.000-11. The participants and their guardians signed the TFIC.

\section{Results}

Of the total of 678 adolescent pupils who participated in the study, $51.5 \%$ were of the male sex. In the evaluation of the socioeconomic conditions of these pupils, a high percentage $(40.4 \%)(\mathrm{N}=274)$ reported being benefited by the "bolsa família" program. It was also observed that $14.6 \%(\mathrm{~N}=99)$ of the interviewees worked in remunerated activities after school, with the higher percentage being among adolescents of the male sex $(18.6 \%)(N=65)$, and differences between sexes being statistically significant $(p=0.002)$.

Among the adolescents $(\mathrm{N}=387)$ who related some type of social and/or economic problems in the community in which they lived, violence/drugs (31.3\%), poverty/infrastructure deficiencies (20.4\%) and inadequate access to health (16.5\%) were ranked first, second and third, respectively, in the list they described. Other problems mentioned in equal proportion were garbage/dirt (12.1\%) and transport (12.1\%).

In the evaluation of aspects related to the social network within the scope of the family, a predominance of the absence of dialogue or space for meeting the adolescents' demands was verified, because the majority reported never/rarely talking to their parents about the difficulties experienced in their day-to-day lives $(64.5 \%)$, with this percentage being even higher among adolescents of the male sex $(72.2 \%),(p=0.000)$. Similarly, $37 \%$ mentioned that their parents had no interest in informing themselves about the activities they performed outside the school environment, in their free time. Moreover, from the perspective of the relationship between adolescents and their parents/guardians, in $27.9 \%$ of the participants' replies, infrequent school attendance without their parents' knowledge was observed. The absence of responsible persons in the pupils' learning process, by means of help with school tasks, for example discussion on subjects related to the disciplines in the courses the adolescents were taking, was mentioned in $70 \%$ of the replies.

Moreover, the data with reference to the quantitative composition of their social relationships of friendship, indicated that $76.7 \%$ of the participants have a group of friends numbering more than seven members, with this proportion being higher among adolescents of the male sex (78.8\%). Nevertheless, when asked about loneliness, $21.7 \%$ related having frequently experienced this feeling, with this percentage being higher among adolescents $(30.7 \%)$ when compared with pupils of the male sex $(13.2 \%),(p=0.000)$. Similarly, a higher proportion of adolescents of the female sex (21.9\%) declared having experienced a situation of frequent insomnia, due to worrying about day-to-day questions.

Evaluation of the time spent on using spoken media (television), and access to the web, which also reports a type of social interaction of the adolescents, demonstrated similar proportions between the adolescents of the male and female sexes. However, the results indicated that adolescents of the male sex spend a longer time daily on virtual games $(72.5 \%)$ and videogames $(70.2 \%),(p=0.000)$ (Table 1$)$. 
Table 1 - Aspects associated with adolescents' social networks, according to sex

\begin{tabular}{|c|c|c|c|c|}
\hline \multirow{3}{*}{ Category } & \multicolumn{2}{|c|}{ Sex } & \multirow{2}{*}{ Total } & \multirow{3}{*}{ p-Value } \\
\hline & Male & Female & & \\
\hline & $n=349(\%)$ & $\mathrm{n}=329(\%)$ & $n=678(\%)$ & \\
\hline Absence from classes without parents' knowledge* & & & & 0.250 \\
\hline$\geq 1$ day & $104(29.8)$ & $85(25.8)$ & $189(27.9)$ & \\
\hline No day & $245(70.2)$ & $244(74.2)$ & $489(72.1)$ & \\
\hline Parents help with homework & & & & 0.132 \\
\hline Frequently & $114(32.7)$ & $90(27.4)$ & $204(30.1)$ & \\
\hline Never/Rarely & $235(67.3)$ & $239(72.6)$ & $474(69.9)$ & \\
\hline Talk over problems with parents & & & & 0.000 \\
\hline Frequently & $97(27.8)$ & $144(43.8)$ & $241(35.5)$ & \\
\hline Never/Rarely & $252(72.2)$ & $185(56.2)$ & $437(64.5)$ & \\
\hline Parents know what you do in your free time & & & & 0.086 \\
\hline Frequently & $209(59.9)$ & $218(66.3)$ & $427(63.0)$ & \\
\hline Never/Rarely & $140(40.1)$ & $111(33.7)$ & $251(37.0)$ & \\
\hline Number of friends the pupil has & & & & 0.183 \\
\hline$\geq 7$ & $275(78.8)$ & $245(74.5)$ & $520(76.7)$ & \\
\hline$\leq 6$ & $74(21.2)$ & $84(25.5)$ & $158(23.3)$ & \\
\hline Was worried and did not sleep at night ${ }^{*}$ & & & & 0.002 \\
\hline Frequently & $45(12.9)$ & $72(21.9)$ & $117(17.3)$ & \\
\hline Never/Rarely & $304(87.1)$ & $257(78.1)$ & $561(82.7)$ & \\
\hline How many times have you felt lonely & & & & 0.000 \\
\hline Frequently & $46(13.2)$ & $101(30.7)$ & $147(21.7)$ & \\
\hline Never/Rarely & $303(86.8)$ & $228(69.3)$ & $531(78.3)$ & \\
\hline Hours/day watching television & & & & 0.173 \\
\hline$\geq 2 \mathrm{~h}$ daily & $178(51.0)$ & $185(56.2)$ & $363(53.5)$ & \\
\hline Not informed & $171(49.0)$ & $144(43.8)$ & $315(46.5)$ & \\
\hline Hours/day playing video-games & & & & 0.000 \\
\hline$\geq 2 \mathrm{~h}$ daily & $245(70.2)$ & $101(30.7)$ & $346(51.0)$ & \\
\hline Not informed & $104(29.8)$ & $228(69.3)$ & $332(49.0)$ & \\
\hline Hours/day playing computer games & & & & 0.000 \\
\hline$\geq 2 \mathrm{~h}$ daily & $253(72.5)$ & $190(57.7)$ & $443(65.3)$ & \\
\hline Not informed & $96(27.5)$ & $139(42.3)$ & $235(34.7)$ & \\
\hline Hours/day on internet/social networks & & & & 0.851 \\
\hline$\geq 2 \mathrm{~h}$ daily & $198(56.7)$ & $189(57.4)$ & $387(57.1)$ & \\
\hline Not informed & $151(43.3)$ & $140(42.6)$ & $291(42.9)$ & \\
\hline
\end{tabular}

*Considering the last 12 months

The information that indicated the vulnerability of these adolescents to drugs considered legal by adults, alcohol and tobacco, showed that $23.6 \%$ and $57.1 \%$ of them had experimented with smoking cigarettes and drinking alcoholic beverages, respectively, without significant differences between the sexes. With reference to drugs considered illegal, for example marijuana, crack, cocaine, it was found that approximately double the adolescents of the male sex $(\mathrm{N}=29 ; 8.3 \%)$ in comparison with the female sex $(\mathrm{N}=14 ; 4.3 \%)$ had experimented with some of these. Statistically significant difference was observed between the sexes for the use of/experimenting with cocaine. As regards the analysis with reference to knowledge about drugs obtained by means of spoken and written media, by educational actions and by direct or indirect contact with these substances, the adolescents mentioned marijuana as being the one they knew best $(67.3 \%)$, followed by cocaine $(48.5 \%)$ and crack $(47.2 \%)$. The drug that presented the lowest percentage of being known by this public was ecstasy (26.1\%).

The research also revealed alarming percentages of adolescents who knew persons close to them that made use of some illegal substance, such as a neighbor $(22 \%)$, friend $(27.9 \%)$, relative $(18 \%)$ school colleague $(19.3 \%)$. Other results about the adolescents' social relationships and use of drugs demonstrated that $28.2 \%$ of these pupils' parents were smokers and $63.6 \%$ of them mentioned having witnessed some situation of violence caused by the excess of alcoholic beverage consumption within the scope of the family or community (Table 2 ). 
Table 2 - Adolescents' behavior, exposure to and knowledge about drugs, according to sex

\begin{tabular}{|c|c|c|c|c|}
\hline \multirow{3}{*}{ Category } & \multicolumn{2}{|c|}{ Sex } & \multirow{2}{*}{ Total } & \multirow{3}{*}{ p-value } \\
\hline & Male & Female & & \\
\hline & $n=349(\%)$ & $\mathrm{n}=329(\%)$ & $n=678(\%)$ & \\
\hline Have tried smoking & & & & 0,401 \\
\hline Yes & $87(24,9)$ & $73(22,2)$ & $160(23,6)$ & \\
\hline No & $262(75,1)$ & $256(77,8)$ & $518(76,4)$ & \\
\hline Smoke & & & & 0,902 \\
\hline Yes & $9(2,6)$ & $8(2,4)$ & $17(2,5)$ & \\
\hline No & $340(97,4)$ & $321(97,6)$ & $661(97,5)$ & \\
\hline Parents smoke & & & & 0,155 \\
\hline Yes & $90(25,8)$ & $101(30,7)$ & $191(28,2)$ & \\
\hline No & $259(74,2)$ & $228(69,3)$ & $487(71,8)$ & \\
\hline Have tried alcoholic beverages & & & & 0,514 \\
\hline Yes & $195(55,9)$ & $192(58,4)$ & $387(57,1)$ & \\
\hline No & $154(44,1)$ & $137(41,6)$ & $291(42,9)$ & \\
\hline Have witnessed violence linked to alcohol & & & & 0,116 \\
\hline Yes & $212(60,7)$ & $219(66,6)$ & $431(63,6)$ & \\
\hline No & $137(39,3)$ & $110(33,4)$ & $247(36,4)$ & \\
\hline I know marijuana & & & & 0,092 \\
\hline Yes & $245(70,2)$ & $211(64,1)$ & $456(67,3)$ & \\
\hline No & $104(29,8)$ & $118(35,9)$ & $222(32,7)$ & \\
\hline I know cocaine & & & & 0,684 \\
\hline Yes & $172(49,3)$ & $157(47,7)$ & $329(48,5)$ & \\
\hline No & $177(50,7)$ & $172(52,3)$ & $349(51,5)$ & \\
\hline I know crack & & & & 0,567 \\
\hline Yes & $161(46,1)$ & $159(48,3)$ & $320(47,2)$ & \\
\hline No & $188(53,9)$ & $170(51,7)$ & $358(52,8)$ & \\
\hline I know a neighbor who uses drugs & & & & 0,153 \\
\hline Yes & $69(19,8)$ & $80(24,3)$ & $149(22,0)$ & \\
\hline No & $280(80,2)$ & $249(75,7)$ & $529(78,0)$ & \\
\hline I know a friend who uses drugs & & & & 0,642 \\
\hline Yes & $100(28,7)$ & $89(27,1)$ & $189(27,9)$ & \\
\hline No & $249(71,3)$ & $240(72,9)$ & $489(72,1)$ & \\
\hline I know a relative who uses drugs & & & & 0,006 \\
\hline Yes & $49(14,1)$ & $73(22,2)$ & $122(18,0)$ & \\
\hline No & $300(85,9)$ & $256(77,8)$ & $556(82,0)$ & \\
\hline I know a school colleague who uses drugs & & & & 0,026 \\
\hline Yes & $56(16,0)$ & $75(22,8)$ & $131(19,3)$ & \\
\hline No & $293(84,0)$ & $254(77,2)$ & $547(80,7)$ & \\
\hline I have tried marijuana* & & & & 0,151 \\
\hline Yes & $21(6,1)$ & $12(3,7)$ & $33(4,9)$ & \\
\hline No & $328(93,9)$ & $317(96,3)$ & $645(95,1)$ & \\
\hline I have tried cocaine ${ }^{*}$ & & & & 0,025 \\
\hline Yes & $12(3,5)$ & $3(1,0)$ & $15(2,2)$ & \\
\hline No & $337(96,5)$ & $326(99,0)$ & $663(97,8)$ & \\
\hline I have tried crack* & & & & 0,996 \\
\hline Yes & $1(0,3)$ & $1(0,3)$ & $2(0,3)$ & \\
\hline No & $348(99,7)$ & $328(99,7)$ & $676(99,7)$ & \\
\hline
\end{tabular}

*The pattern of use was not investigated

The information about violence suffered by the pupils were shown to be alarming, because $15 \%$ of the interviewees had suffered some type of aggression in the last year and $26.7 \%$ of them said that they had been involved in fights once or twice in the year, with this being more common among adolescents of the male sex $(p=0.000)$. Moral harassment or bullying that affects the adolescents' social relationships, particularly within the scope of school, also demonstrated alarming results, as $28.3 \%$ of them related this type of violence. 


\section{Discussion}

The relationship between the adolescents' vulnerability to health and their socioeconomic conditions showed that work in adolescence is a theme of importance to social policies. Work in adolescence, in the majority of cases, is associated with a low economic condition, since it represents one of the personal or family strategies to provide their basic needs, guaranteeing help with paying expenses or acquisition of consumer goods ${ }^{(6-7)}$. Indeed, the results of this study showed an alarming percentage of adolescents who work, coming from families in a condition of poverty. This condition was identified by the high percentage of beneficiaries of the "Bolsa Família" Program, of which one of the inclusion criteria is the family's low socioeconomic level. Another aspect refers to the risks for health of the adolescent worker, who is more exposed to an overload of activities that may result in a reduction in socializing with the persons who are part of his/her social network, and cause physical and mental weariness, commonly associated with harm to health ${ }^{(6-8)}$.

The FHS/SHPs may include this discussion in their list of themes destined for health care in adolescence within the scope of school, particularly in the regions in which there are higher levels of poverty and the occurrence of work in adolescence is more frequent. In this debate, it is important to include the possible relationship of gender in work in adolescence, shown in this study by the higher proportion of pupils of the male sex who reported that they were working.

The study demonstrated that adolescents establish a wide social network, mainly composed of friends from the school environment, and by those that form part of social spaces on the web, for example, Facebook. Adolescence is a period in which the company of parents or family members, in general, is not sufficient, driving adolescents to seek to widen their network of friends. If, on the one hand, this contributes to the construction of identity, respect, generosity, tolerance, loyalty and other attributes considered positive(8), on the other, the group trend may lead to situations of risk to the health of these adolescents, by their greater exposure to situations of vulnerability. Adolescents who socialize with individuals who smoke, drink or use drugs, tend to acquire such behaviors, as well as aggressive and illegal conducts, in addition to concern about their body image ${ }^{(9-14)}$.

Although the results showed a wide network of friends among the participants, a considerable proportion of the adolescents related having experienced the feeling of loneliness. This feeling, and sleep disturbances, which were also related by the interviewees, demonstrates that the harm to mental health in adolescence are relevant in planning the health care of this group. In this study, these situations were associated with worries about dayto-day facts, which could be the consequence of little dialogue with their parents/guardians, related by the majority of the participants.

Indeed, because adolescence is marked by various transformations in the psychological area, such as the construction of self-concept, identity, self-esteem and other more complex aspects within the scope of social relationships, it frequently causes feelings of inquietude and doubt, which may make individuals at this stage susceptible to harm to mental health ${ }^{(15-16)}$. It is important to point out that this study demonstrated that there appears to be a relationship between gender and the situations of harm to mental health investigated; and the feeling of loneliness and day-to-day worries, with insomnia related by adolescents of the female sex.

The adolescents informed that they spent a considerable amount of time on the web and watching television programs, which could lead to sedentarism with risks for chronic, non transmittable diseases ${ }^{(17)}$. With reference to the spoken media in Brazil, there is always a specific program for adolescents, which seeks to portray the stereotypes and common aspects shared by this group, for example, some of the soap operas on television. However, a study in this area ${ }^{(18)}$ showed that the youngsters did not identify themselves with the characters in these programs, but desired their modes of being and patterns of consumption, which for many, are not possible, and expose them to situations of social inequality. From another perspective, these programs also help adolescents to understand their universe and the social reality in which they are inserted. Thus, they could be important tools in health education, considering that part of these programs could be used by educators and health professionals in the debate about vulnerability in adolescence.

The use of the web has positive points, such a increasing the number of "virtual" friends, as previously mentioned, thereby enabling feelings and experiences to be shared among adolescents, in addition to providing access to information. Its disadvantages as regards adolescents' health are related to compromising learning, isolation, sedentarism, anxiety or even depression ${ }^{(19)}$. Therefore, it is important for parents to participate in and monitor adolescents' use of the internet. This does not mean only blocking sites that are inappropriate for 
this age group, but it involves introducing permanent discussions into the sphere of the family, about the use of the web and its impact on people's cognitive, affective and social development.

Nevertheless, the results of this study showed the absence of dialogue between adolescents and their parents/guardians as a factor causing concern, since the family exerts great influence on the process of the individual's development, which includes educational, socialization and health care practices. It should be emphasized that adolescence is a period of great changes, discoveries and doubts, and in this sense, dialogue within the scope of the family is of central importance, so that the adolescent achieves the best adaptation possible to the transformations occurring in this phase ${ }^{(20)}$. Therefore, it is of the utmost importance for this group to share their problems and establish confidence in dialogue with their parents/guardians. Studies $^{(10,14)}$ have pointed out parental practices, such as interest in their children's activities, knowing their friends, and what they do in their free time, are important in reducing vulnerabilities.

Absence of deficient family dialogue may also be associated with the experiences of drug consumption by adolescents, as shown in this study by the considerable proportion of youngsters who have experimented cigarette smoking and drinking alcoholic beverages, however, at a lower percentage that that shown in a study of national coverage ${ }^{(21)}$. In addition to these factors, authors have affirmed that the consumption of alcoholic beverages and smoking among adolescents is also explained by the easy access to these substances at parties, in bars or in their own homes, and by the influence of the spoken and written media.

It was observed that some adolescents related having experimented with other drugs, such as marijuana and crack, confirming the alarming insertion of these substances among youngsters, and corroborating the result of the broad study by the World Health Organization covering 40 countries, in which $18 \%$ of the youngsters aged 15 years had experimented with marijuana ${ }^{(22)}$. There are evidences that access to information is one of the protective factors against the use of drugs( ${ }^{(23)}$, which places this as a central subject of the health care practices in the FHS/SHPs. It should be pointed out that these actions should exceed the merely informative aspect, with processes that favor the adolescents' expression of opinion, attitude and behavior as regards this subject. In this study, in spite the intense dissemination in the media about the crack epidemic in Brazil, marijuana continues to be the best known drug among the adolescents investigated.

Another relevant result about the vulnerability of adolescents to drugs was the high percentage of youngsters who reported knowing someone close to them who made use of an illegal substance. Indeed, as previously mentioned, the social network, particularly that closest to the adolescent, such as family and friends exert an influence on the behavior of refusal to use, or of using drugs(10).

However, the problem of drugs among youngsters reveals a complex and multifactorial etiology. Inserted into this debate, in addition to subjective and cultural aspects, are the adolescents' social networks, contexts of violence in which they may be inserted and their association with the risks of drug use. In this study a high percentage of reports were identified, made by adolescents who had witnessed scenes of violence within the scope of the family or community as a result of excessive ingestion of alcoholic beverages. Indeed, adolescents who are victims of maltreatment, or witness aggression against the mother by the father or stepfather, appear to be more susceptible to harm to mental health, which compromises their self-confidence and self-esteem $^{(24)}$.

In this study, the investigation of violence in its different scenarios showed that adolescents were victims of some type of aggression, or were involved in fights, in addition to having suffered bullying by their colleagues. Bullying is a subject that has been amply debated nowadays, since it causes psychic suffering, diminished self-esteem, isolation and damage to learning(25). Therefore, violence in the family and school context, and in the adolescents' different social spaces must be the object of more profound investigations with regard to its impact on adolescents' health.

This investigation is differentiated from other studies in this thematic area(6-7,9-16,18-21,25) because it presents an approach that integrates important vulnerabilities to health in adolescence, such as the problems that involve social networks, economic and social factors, for example the need to work, violence and experimenting with/consumption of drugs.

\section{Conclusions}

This study showed that a large portion of adolescents com from poor families, beneficiaries of the "bolsa família", and frequently these youngsters have to perform a remunerated activity after school to help 
with supporting the home. Violence, both within the family and community, almost always associated with the use of drugs, poverty, precarious infrastructure such as deficient garbage collection, difficulties with transport and access to health, were pointed out by the adolescents as the main social and/or economic problems experienced in the community.

With reference to the social network within the scope of the family, the results showed an absence of dialogue between parents and children, and the demands of adolescents not being met. It was evident that the parents were not interested in what the adolescents did outside of school, and were frequently not involved in their learning process. A large portion of the adolescents of both sexes had ingested some type of alcoholic beverage, and a small portion had experimented with cigarette smoking and drugs that were illegal for adults, such as marijuana, crack and cocaine. Bullying was pointed out as one of the aggressions suffered by the adolescent, mainly at school.

The digital social networks, games and television were shown to be devices of leisure, communication and socialization strongly used by the investigated adolescents. It is pointed out that the tools of the web, for example, the social networks appeared to emerge as a vehicle with high potential for the practices of health education directed towards this group, and so was television. Also evidenced, was the need for investment in health actions that seek to develop not only the cognitive competences linked to the broadening of the adolescents' conceptual level of subjects on health, but also affective and social competences that lead to improvement in the way in which this group positions itself in the face of questions of vulnerability.

The results of this study demonstrated the need for greater investments in public health actions performed by the FHS/SHPs, in a collaborative manner with the various social actors in the adolescents social life, such as health professionals, educators and family, in addition to partnerships with tutorship councils and nongovernmental organizations. As a recommendation, greater effort by governments in the promotion of systematic and periodical campaigns is suggested, using the spoken and written media in divulging the vulnerabilities to adolescents' health, with the family as their great ally.

\section{References}

1. Brêtas JRS. Vulnerabilidade e adolescência. Rev Soc Bras Enferm Ped. 2010;10(2):89-96.

2. Guimarães MCS, Novaes SC. Autonomia reduzida e vulnerabilidade: liberdade de decisão, diferença e desigualdade. Rev Bioética. 2010;7(1):21-4.

3. Ferrari RAP, Thomson Z, Melchior R. Atenção à saúde dos adolescentes: percepção dos médicos e enfermeiros das equipes da saúde da família. Cad Saúde Pública. 2006;22(11):2491-5.

4. Brêtas JRS, Ohara CVS, Jardim DP, Aguiar JW, Oliveira JR. Aspectos da sexualidade na adolescência. Rev Ciênc Saúde Coletiva. 2011;16(7):3221-8.

5. World Health Organization. School health and youth health promotion. [acesso 30 mar 2012]. Disponível em; http://www.who.int/school_youth_health/en/.

6. Torres CA, Paula PHA, Ferreira AGN, Pinheiro PNC. Adolescência e Trabalho: significados, dificuldade e repercussões. Interface - Comunic Saude Educ. 2010;14(35):839-50.

7. Oliveira BRG, Robazzi MLCC. O trabalho na vida dos adolescentes: alguns fatores determinantes para o trabalho precoce. Rev. Latino-Am. Enfermagem. 2001;9(3):83-9.

8. Barreiro IMF. Formação de valores e identidade na adolescência: uma experiência. Rev Ciênc Ext. 2010;1:184-9.

9. Zeitoune RCG, Ferreira VS, Silveira HS, Domingos AM, Maia AC. O conhecimento de adolescentes sobre drogas lícitas e ilícitas: uma contribuição para a enfermagem comunitária. Esc Anna Nery. [periódico na Internet] 2012;16(1):57-63.

10. Garcia JJ, Pillon SC, Santos MA. Relações entre contexto familiar e uso de drogas em adolescentes de ensino médio. Rev. Latino-Am. Enfermagem. 2011;19:753-61.

11. Barroso T, Mendes A, Barbosa A. Analysis of the alcohol consumption phenomenon among adolescents: study carried out with adolescents in intermediate public education. Rev. Latino-Am. Enfermagem. 2009;17(3):347-53.

12. Ferreira MMSRS, Torgal MCLFPR. Consumo de tabaco e de álcool na adolescência. Rev Latino-Am. Enfermagem. 2010;18(2):122-9.

13. Jinez MLJ, Souza JRM, Pillon SC. Uso de drogas e fatores de risco entre estudantes de ensino médio. Rev. Latino-Am. Enfermagem. 2009;17(2):246-52.

14. Cid-Monckton $P$, Pedrão LJ. Factores familiares protectores y de riesgo relacionados al consumo de drogas en adolescentes. Rev. Latino-Am. Enfermagem. 2011;19(spe):738-45.

15. Avanci JQ, Assis SG, Oliveira RVC, Ferreira RM, Pesce RP. Fatores associados aos problemas de saúde mental em adolescentes. Psic Teor Pesq. 2007;23(3):287-94. 
16. Benetti SPC, Pizzeta A, Schwartz CB, Hass RA, Melo VL. Problemas de saúde mental na adolescência: características familiares, eventos traumáticos e violência. Psico-USF 2010;15(3):321-32.

17. Malta DC, Sardinha LMV, Mendes I, Barreto SM, Giatti L, Castro IRR, et al. Prevalência de fatores de risco e proteção de doenças crônicas não transmissíveis em adolescentes: resultados da Pesquisa Nacional de Saúde do Escolar (PeNSE), Brasil, 2009. Ciênc Saúde Coletiva. 2010;15(2):3009-19.

18. Njaine K. Sentidos da violência ou violência sem sentido: o olhar dos adolescentes sobre a mídia. Interface - Comunic Saude Educ. 2006;10(20):381-92. 19. O'Keeffe GS, Clarke-Pearson K. Council on communications and media. American Academy of Pediatrics. Clinical Report: The Impact of Social Media on Children, Adolescents, and Families. 2011. [acesso 4 Jun 2012]. Diponível em: http://pediatrics.aappublications. org/content/early/2011/03/28/peds.2011-0054.full. pdf+html

20. Pratta EMM, Santos MA. Família e adolescência: a influência do contexto familiar no desenvolvimento psicológico de seus membros. Psicol Estud. 2007;12(2):247-56.

21. Malta DC, Mascarenhas MDM, Porto DL, Duarte EA, Sardinha LM, et al. Prevalência do consumo de álcool e drogas entre adolescentes: análise dos dados da Pesquisa Nacional de Saúde Escolar. Rev Bras Epidemiol. 2011;14(1):136-46.

22. World Health Organization (WHO). Inequalites in young people's health. Health Behavior in School- Aged Children. International Report from 2005-2006. Health Police for Children and Adolescents. 2008. [acesso 24 Mai 2012]. Disponível em: http://www.euro.who.int/ en/what-we-do/health-topics/Life-stages/child-andadolescent-health/publications/2008/inequalities-inyoung-peoples-health.-hbsc-international-report-fromthe-20052006-survey

23. Sanchez ZVDM, Oliveira LG; Ribeiro LA, Nappo SA. O papel da informação como medida preventiva ao uso de drogas entre jovens em situação de risco. Ciênc Saúde Coletiva. 2010;15(3):699-708.

24. Nunes CB, Sarti CA, Ohara CVS. Conceptions held by health professionals on violence against children and adolescents within the family. Rev. Latino-Am. Enfermagem. 2008;16(1):136-41.

25. Moura DR, Cruz ACN, Quevedo LA. Prevalência e características de escolares vítimas de bullying. J Pediatr. 2011;87(1):19-23. 